\title{
STATUTORY ADOPTION OF THE COMMON LAW IN THE WEST, AND HEREIN OF ITS INTRODUCTION INTO IOWA.
}

That American legal and political institutions everywhere bear the stamp and breathe the spirit of the Common Law of England is a leading phenomenon in the development of the New World, and one that has not escaped observation. Students of American Politics have not failed to note the cause of this striking phenomenon; the Bar admires it for the "even-handed and enlightened justice it has dispensed;" ' while others wisely venerate where they "are not presently able to comprehend."

And what is true of American institutional development in general is true of the more particular development that has taken place in lowa; for the institutions of this commonwealth appear as sequences in that broader development which is termed American. That is to say, a leading phenomenon in the Latw and Politics of Iowa is the presence of the spirit and principles of the Common Law of England.

America was colonized largely by Englishmen. And during the period of institutional infancy it was under the political control of the Mother Country. Indeed, America was then a part of England and the inhabitants were Englishmen by law as well as by birth. As a consequence "the supreme law of the land" was from the beginning the Common Law supplemented by the Statutes of Parliament. Magna Charta was pleaded in the courts. "

The Declaration of Independence swept away the supremacy of King and Parliament so far: as the colonies

1 "The Laws and Iurisprudence of England and America," by John F. Dillon, p. 136.

2 Bowman v. Middleton, 1 Bay (S. C.) 254 . 
were concerned. But that declaration did not (could not) disturb the fundamental principles of Law and Politics: everywhere they continued to 'exist, being perpetuated through (1) constitutions, (2) statutes, and (3) judicial decisions. The legislator continued to formulate "general rules of conduct" along the old lines and in accordance with old models. While the judge, always more or less bounded by the written letter of the law, went on interpreting the "general rules" in the light of "judicial precedents." It is significant that legislator and judge have cooperated in the work of infusing into our legal and political institutions the spirit and principles of the Common Luw. That the infusion has been wide-spread and thorough is evidenced both by statute law and by case law.

It is, however, to the statutory adoption of the Com. mon Law in the Great West, and herein of its introduction into Towa, ${ }^{1}$ that I desire to make special reference in this connection. Now it is well known that the famous Ordinance of.1787 was the leading statute through which the principles of the Common Law were transmitted and guaranteed to the West. Subsequent iucts of Congress providing for the organization and government of the Territories followed more or less closely the outline of the great Ordinance. And here it must not be forgotten that congressional legislation was supported by local legislation in the Territories and Commonwealthis. The influence of the Ordinance and of the other acts of Congress has been repeatedly observed and noted by jurists and students of American History. But little or no mention is made of that local legislation which best illustrates, as it seems to me, the thorough and almost unconditional adoption of English Law.

With special reference to the History of Iowa there are two statutes which bear out the thought above ex-

1 See "The Introduction of the Common Law into Iowa," by Chancellor McClain.-Iowa Historical Lectures, 1892: p. 70. 
pressed and clearly illustrate the wholesale adoption of English Jurisprudence. The one is a statute of the General Assembly of the Territory of Missouri, enacted in the year: 1816. ${ }^{\circ}$ It reads as follows:

"The common law of Fingland, which is of a general "nature, and all stitutes made by the Eiritish pirliament "in aid of or: to supply the defects of the said common law, "made prior" to the fourth year' of James the first," and of "a general nature, and not local to that kingdom, which "said 'common law and statutes are not contrary to the "laws of this territory, and not repumnant to, nor incon"sistent with the constitution and laws of the United "States shall be the rule of decision in this territory, until "altered or repealed by the legislature, any law, usiage, or "custom to the contrary notwithstanding, movided 7.ovever, "that' none of the British statutes respecting crimes and "punishments shall be in forcelin this territory, nor shall "any person be punished by common law, where the laws "and statutes of this territory have made provision on the "subject, but where the laws and statutes of the United "States and this territory have not made provision for the "punishment of offenses, the several courts may proceed "to punish for such offenses; mrovided, the punishment "shall in no case be other than five and imprisonment, and "the term of imprisonment shall not exceed two months; "and the fine shall not exceed one hundred dollars."

"2. The doctrine of survivorship in cases of joint "tenants shall never be allowed, in this territory. The "doctrine of entails shall never be allowed, and in all cases "where any real estate shall be entailed, the whole of the "right and interest of, in, and to the same, shall vest in "fee simple in the person having the first reversion or "remainder in said estate, after the life estate is determined "in said estate." "

1 The geographical area of the Commonwealth of Iowa was at that time included within the Territory of Missouri.

2 Shambaugh's "Documentary Material relating to the History of Iowa," No. 2, p. 41. 
The other statute which is aptly illustrative of the adoption of the Common Law in the West, and herein of its introduction into Iowa, was enacted by the Governor and Judges of the Territory Northwest of the River Ohio in the year 1795. This statute adopted from the statutes of Virginia reads :

"The common law of England, all statutes or acts of "the British parliament made in aid of the common law, "prior to the fourth year of the reign of King James the "first (and which are of a general nature, not local to that "kingdom) and also the several laws in force in this terri"tory, shall be the rule of decision, and shall be considered. "as of full force, until repealed by legislative authority "or disapprored of by congress." "

Slate University of Lown, Benjamin F. Shambaugh. lown Cily, Iowa.

Des Moines Flfty Yrars Ago. - A correspondent of the Miners Express of Dubuque, September 15, 1847, in an article descriptive of the "New Purchase", (Iowa), thus describes the future capital of Iowa: "A short distance above the junction of the Raccoon and Des Moines rivers is the old Fort, or Fort Des Moines, as it is called. This Fort was evacuated by the United States Dragoons on the 10th of March, 1846. Since that time a town has sprung up numbering within its limits some one hundred and fifty inhabitants. There are few countries that present more inducements to emigrants than this. Excellent claims may be had in Polk county for the trouble of staking them out and putting up a cabin. The population of the county is estimated at 1,500."

1 Shambaugh's "Documentary Material relating to the History of Jowa," No. 3, p.48. For a statute of the Territory of Michigan repealing the statutes of Parliament, see "Documentary Material, etc," No. 3, p. 74 . 
Copyright of Annals of Iowa is the property of State of Iowa, by \& through the State Historical Society of Iowa and its content may not be copied or emailed to multiple sites or posted to a listserv without the copyright holder's express written permission. However, users may print, download, or email articles for individual use. 